\title{
Рідкісні анатомічні варіанти басейну нижньої брижової артерії на передопераційному та інтраопераційному етапах у пацієнтів, яким виконуеться Д3 лімфодисекція зі збереженням лівої ободової артерії
}

\begin{abstract}
Мета роботи: провести аналіз рідкісних варіантів анатомії басейну нижньої брижової артерії та вивчити труднощі, які можуть ускладнювати та збільшувати час проведення ДЗ лімфодисекції із збереженням лівої ободової артерії.

Матеріали і методи. У дослідженні брали участь 103 пацієнти (56 чоловіків та 47 жінок; середній вік (64,2士11,6) року), хворих на рак лівої половини ободової та прямої кишок, яким виконали передопераційну ЗД-КТ ангіографію в Тернопільській університетській лікарні в період 2016 - 2021 рр. У даному дослідженні ми ставили наступні завдання: визначити тип нижньої брижової артерії, відстань від гирла нижньої брижової артерії до біфуркації аорти, відстань від нижньої брижової артерії до лівої ободової артерії, відстань від лівої ободової артерії до місця перехресту з нижньою брижовою веною.

Результати досліджень та їх обговорення. Всім пацієнтам виконано ДЗ лімфодисекцію зі збереженням лівої ободової артерії. У жодного пацієнта не виникла неспроможність швів анастомозу. Середня кількість видалених лімфатичних вузлів становила 21,4 \pm 7,1 (12-45). Частота метастатичного ураження апікальної групи лімфатичних вузлів становила 7,5 \%. Одними з найрідкісніших варіантів розгалуження нижньої брижової артерії за Зебровським є типи C, D та G. B нашому дослідженні ми встановили, що відстань відходження лівої ободової артерії від нижньої брижової артерії становить (35,29 $\pm 10,18)$ мм (11-66 мм). Особливо слід звернути увагу на клінічні випадки, коли відстань відходження лівої ободової артерії від нижньої брижової артерії становила більше 5 см, що також створює труднощі в збільшенні часу операції, необхідної для скелетизації вищезгаданих судин та дотримання всіх онкологічних канонів ДЗ лімфодисекції. Ми виявили рідкісні випадки високого відходження нижньої брижової артерії на рівні ниркових артерій. Ще одним орієнтиром, на який слід звертати увагу, є перехрест лівої ободової артерії з нижньою брижовою веною, який згідно з нашим аналізом, становить $(20,97 \pm 13,59)$ мм (діапазон 2-65).
\end{abstract}

Ключові слова: ЗД-КТ ангіографія; колоректальний рак; ДЗ лімфодисекція, ліва ободова артерія.

Постановка проблеми і аналіз останніх досліджень та публікацій. Неспроможність швів анастомозу (НША) - це найбільш небажане ускладнення в колоректальній хірургії і за різними даними становить 10-50 \%. Велику кількість усіх випадків колоректального раку (КРР) становлять ускладнені форми, а саме обтураційна кишкова непрохідність. За таких обставин перед хірургом постає одразу два серйозних завдання: усунення непрохідності та виконання онкологічно радикального операційного втручання [5]. Одним із найсуттєвіших етіологічних чинників НША $\epsilon$ порушення кровопостачання обох кінців анастомозу. В літературі досі триває дискусія про місце лігування нижньої брижової артерії (НБА) при виконанні ДЗ лімфодисекції з приводу лівобічного КРР. Загальноприйнятими є дві методики: лігування НБА в основі відходження від аорти та лігування НБА дистальніше відходження лівої ободової артерії (ЛОА) [3, 4, 6]. Лігування НБА в основі відходження від аорти дає можливість одним блоком провести ДЗ лімфодисекцію та працювати в правильних анатомічних шарах [6]. Лігування НБА нижче відходження ЛОА дає можливість зберегти цю важливу судину для адекватного кровопоста- чання лівих відділів товстого кишечника та, відповідно, знизити ризик НША [3, 4]. Проте слід також зважати, що дана опція є більш технічно складна та вимагає скелетизації НБА та її гілок іноді на досить широкому протязі [3]. Складності виконання таких операцій додають ще і різні анатомічні варіанти будови НБА та ії гілок.

Широко впроваджена в клінічну практику ЗД-КТ ангіографія дає можливість провести аналіз судинної анатомії на доопераційному етапі та мати чітку ЗД реконструкцію під час виконання ДЗ лімфодисекції із збереженням ЛОА [1, 2]. Досить важливим $€$ факт чітко дотриматися протоколу сканування, а також враховувати індивідуальні коморбідні аспекти кожного пацієнта, які можуть впливати на якість отриманих даних.

Мета роботи: проаналізувати класичні та рідкісні клініко-радіологічні аспекти, які, як правило, потрібно розглянути перед операцією мультидисциплінарній команді з приводу раку лівої половини товстої та прямої кишки. Провести аналіз рідкісних варіантів анатомії басейну НБА та вивчити труднощі, які можуть ускладнювати та збільшувати час проведення Д3 лімфодисекції із збереженням ЛОА. 
Матеріали і методи. У дослідженні брали участь 103 пацієнти (56 чоловіків та 47 жінок; середній вік $(64,2 \pm 11,6)$ року) на рак лівої половини ободової та прямої кишок, яким виконали передопераційну ЗД-КТ ангіографію у Тернопільській університетській лікарні впродовж 2016-2021 рр.

У даному дослідженні ми ставили наступні завдання: визначити тип НБА, відстань від гирла НБА до біфуркації аорти, відстань від НБА до ЛОА, відстань від ЛОА до місця перехресту з нижньою брижовою веною.

Протокол сканування: ЗД-КТ ангіографію проводили за допомогою KT-апарату Philips Brilliance 64 з в/в контрастуванням (100 мл йод-контрастного препарату (370 мг / мл)), вводили в ліктьову вену зі швидкістю 4,5 мл/с. Для сканування використовувався метод болюсного відстеження. Сканування артеріальної фази автоматично розпочинали, коли контрастність у черевній аорті на рівні черевного стовбура досягла 180HU. 64-зрізовий мультидетекторний сканер KT (MDCT) може генерувати зрізи 0,75 мм, які можна реконструювати в зображення 0,5 мм. Отже, щоб отримати якісну КT-ангіографію для передопераційного аналізу слід підтримувати протокол сканування: сублінгвальне приймання нітратів, висока швидкість введення контрасту (4-5 мл / с), рання артеріальна фаза (20-30’), зниження “напруги” (80-100kV), збільшення мАс в два рази. Аналіз обробки зображень проводили за допомогою техніки візуалізації 3D-об’єму, VRT.

Статистичний аналіз виконано за допомогою програмного забезпечення Statistica 64. Порядкові дані були обраховані з використанням медіани.
Результати досліджень та їх обговорення. Всім пацієнтам виконали ДЗ лімфодисекцію зі збереженням ЛОА. У жодного пацієнта не виникла неспроможність швів анастомозу. Середня кількість видалених лімфатичних вузлів становила 21,4 \pm 7,1 (12-45). Частота метастатичного ураження апікальної групи лімфатичних вузлів становила 7,5 \%. Передопераційний радіологічний та інтраопераційний аналізи показали, що нижня брижова артерія була присутня у 100 \% випадків. Відповідно до класифікації розгалуження НБА за Зебровським виділено 8 найчастіших варіантів будови НБА [7]. Тип А виявлено у 35 (34 \%) пацієнтів, тип В - у 28 (27,2 \%) пацієнтів, тип С - у 3 (2,9 \%) пацієнтів, тип D - у 4 (3,9 \%) пацієнтів, тип $\mathrm{E}$ - y 7 (6,8 \%) пацієнтів, тип F - у 7 (6,8 \%) пацієнтів, тип $\mathrm{G}$ - у 6 (5,8 \%) пацієнтів та тип $\mathrm{H}$ - у 13 (12,6 \%) пацієнтів. Одними з найрідкісніших варіантів НБА, відповідно, $є$ типи C, D та G (рис. 1).

Відстань між НБА та біфуркацією аорти становила $(45,8 \pm 9,6)$ мм. Важливим фактором, який суттєво впливає на тривалість та складність виконання ДЗ лімфодисекції із збереженням ЛОА, є відстань від основи НБА до місця відгалуження ЛОА. Ми підрахували, що середня відстань від основи НБА до місця відгалуження ЛОА становила (35,29 $\pm 10,18)$ мм (11-66 мм). У випадках найбільшої відстані (більше 55 мм) відходження ЛОА спостерігається на рівні лівої клубової артерії (рис. 2 (Б)). Ми виявили рідкісні випадки високого відходження НБА на рівні ниркових артерій (рис. 2 (А)).

Для уникнення пошкодження судинної стінки під час виконання ДЗ лімфодисекції із збереженнями ЛОА дуже важливо розуміти анатомічне
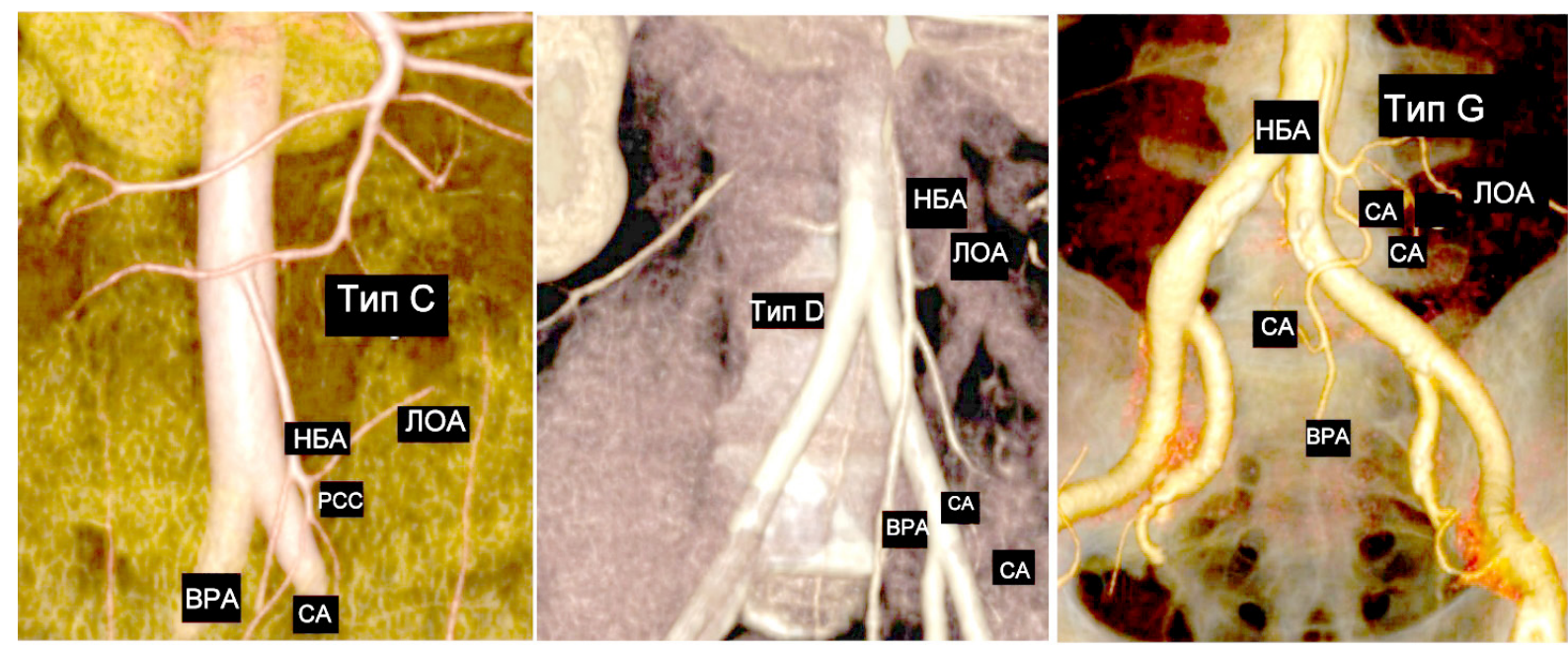

Рис. 1. Рідкісні типи C, D та G розгалуження НБА за Зебровським (НБА - нижня брижова артерія, ЛОА - ліва ободова артерія, РСС - ректосигмоїдний стовбур, СА - сигмоподібна артерія, ВРА - верхня ректальна артерія). 


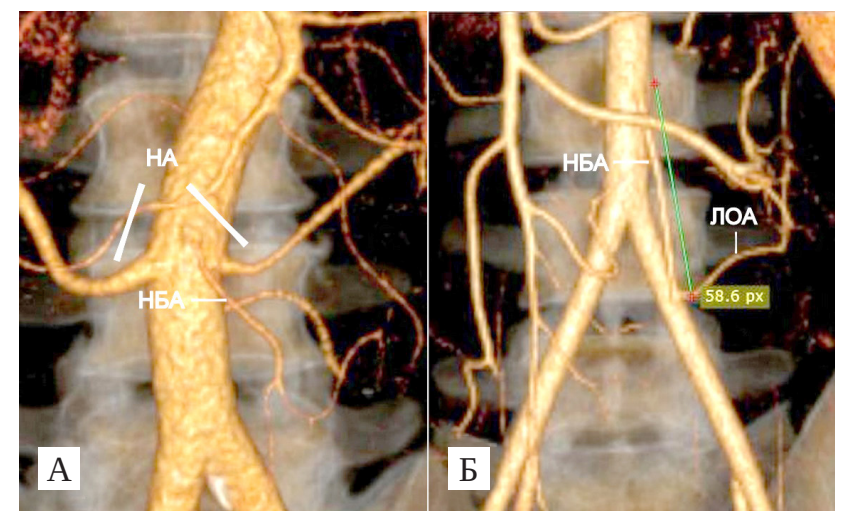

Рис. 2. ЗД-КТ реконструкція відходження НБА на рівні ниркових артерій (А), відходження ЛОА від НБА на рівні лівої загальної клубової артерії на відстані 60 мм (Б) (НА - ниркові артерії, НБА - нижня брижова артерія, ЛОА - ліва ободова артерія).

співрозташування між ходом ЛОА та її перехрестом із нижньою брижовою веною (НБВ). Наш аналіз показав, що ЛОА перехрещується з НБВ по передній стінці на відстані $(20,97 \pm 13,59)$ мм (діапазон 2-65).

Найбільш небажаним ускладненням у ранньому післяопераційному періоді у пацієнтів на КРP $є$ НША. Ключовими факторами, які впливають на НША, є стан кровопостачання країв анастомозу та його натяг [5]. В літературі досі триває активна дискусія про місце лігування НБА при виконанні операцій з приводу раку лівих відділів ободової та прямої кишки [3, 4, 6]. Прихильники лігування НБА в основі вказують на те, що є краща мобільність проксимального сегмента кишки при виконанні передньої резекції прямої кишки, більша кількість видалених апікальних лімфатиних вузлів [6].

Натомість збереження ЛОА має ряд суттєвих переваг, зокрема це краще кровопостачан- ня зони анастомозу, що, у свою чергу, зменшує ризик НША, зниження ризику пошкодження гіпогастральних нервів та, відповідно, зниження сечостатевих порушень [3]. Серед нашої групи пацієнтів ми не спостерігали жодного випадку неспроможності швів анастомозу. Серед недоліків збереження ЛОА є збільшення часу операцій, оскільки технічно складніше провести ДЗ лімфодисекцію апікальних лімфовузлів, потенційно більша частота пошкодження судинної стінки [4].

У нашому дослідженні ми виявили, що відстань відходження ЛОА від НБА становить (35,29 \pm 10,18) мм (11-6 6мм). Особливо слід звернути увагу на клінічні випадки з відстані відходження ЛОА від НБА більше 5 см (рис. 2 (Б)), що також становить труднощі в збільшені часу операції, необхідної для скелетизації вищезгаданих судин та дотримання всіх онкологічних канонів ДЗ лімфодисекції $[1,2,4]$. Ще одним орієнтиром, на який слід звертати увагу, є перехрест ЛОА з НБВ, який згідно з нашим аналізом становить (20,97 \pm 13,59) мм (діапазон 2-65). Даний аналіз є важливим, оскільки НБВ має бути лігована біля нижнього краю горизонтальної частини ДПК. При виконанні ДЗ лімфодисекції зі збереженням ЛОА це суттєво, оскільки це збільшує час операції з метою виділення та лігування НБВ у вищевказаному місці.

Висновки. 1. ДЗ лімфодисекція із збереженням ЛОА дає можливість виконати онкологічно радикальне операційне втручання зі зменшенням ризику розвитку неспроможності швів анастомозу.

2. Ретельний передопераційний аналіз судинної анатомії на ЗД-КТ ангіографії дасть можливість оцінити складність виконання ДЗ лімфодисекції, зменшити інтраопераційний час на ідентифікацію структур та виробити персоніфіковану стратегію на операцію.

\section{СПИСОК ЛІТЕРАТУРИ}

1. Anatomic variations of inferior mesenteric artery and left colic artery evaluated by 3-dimensional CT angiography: Insights into rectal cancer surgery. A retrospective observational study / Jia Ke, Jiawei Cai1, Xiaofeng Wen [et al.] // International Journal of Surgery. - 2017. - Vol. 41. - P. 106-111.

2. Anatomy of the inferior mesenteric artery evaluated using 3-dimensional CT angiography / K. Murono, K. Kawai, S. Kazama [et al.] // Dis. Colon Rectum. - 2015. - Vol. 58. - P. 214-219. 3. Clinical impact of D3 lymph node dissection with left colic artery (LCA) preservation compared to D3 without LCA preservation: Exploratory subgroup analysis of data from JCOG0404 / Tomonori Akagi, Masafumi Inomata, Takao Hara [et al.] // Ann. Gastroenterol. Surg. - 2020. - Vol. 4. - P. 163-169.

4. Anatomical study of the left colic artery in laparoscopic-assist-

ed colorectal surgery / Wei Zhang, Wei-Tang Yuan, Gui-Xian Wang [et al.] // Surg. Endosc. - 2020. - Vol. 34 (12). - P. 5320-5326.

5. The evaluation of risk factors of anastomotic leakage in patients with colorectal cancer complicated by ileus / Yosyp Grytsenko, Anatoliy Bedeniuk, Stepan Grytsenko [et al.] // International Journal of Surgery and Medicine. - 2017. - Vol. 3 (4). - P. 205-210.

6. Preservation versus non-preservation of left colic artery in sigmoid and rectal cancer surgery: A meta-analysis / Yu-Chen Fana, Fei-Long Ninga, Chun-Dong Zhanga [et al.] // International Journal of Surgery. - 2018. - Vol. 52. - P. 269-277.

7. Variations of origin and branching of the interior mesenteric artery and its anastomoses / W. Zebrowski, E. Augustyniak, S. Zajac // Folia Morphol. (Warsz). - 1970. - Vol. 30. - P. 510517. 


\section{REFERENCES}

1. Jia Ke, Jiawei Cai1, Xiaofeng Wen, Xianrui Wu, Zhen He, Yifeng Zou, ..., \& Ping Lan (2017). Anatomic variations of inferior mesenteric artery and left colic artery evaluated by 3-dimensional CT angiography: Insights into rectal cancer surgery. A retrospective observational study. International Journal of Surgery, 41, 106-111. DOI: 10.1016/j.ijsu.2017.03.012

2. K. Murono, K. Kawai, S. Kazama, S. Ishihara, H. Yamaguchi, E. Sunami, ..., \& Watanabe (2015). Anatomy of the inferior mesenteric artery evaluated using 3-dimensional CT angiography. Dis. Colon Rectum, 58, 214-219. DOI: 10.1097/ DCR.0000000000000285.

3. Tomonori Akagi, Masafumi Inomata, Takao Hara, Junki Mizusawa, Hiroshi Katayama, Dai Shida, ..., \&, Seigo Kitano. (2020). Clinical impact of D3 lymph node dissection with left colic artery (LCA) preservation compared to D3 without LCA preservation: Exploratory subgroup analysis of data from JCOG0404. Ann. Gastroenterol. Surg., 4, 163-169. DOI: 10.1002/ags3.12318 4. Wei Zhang, Wei-Tang Yuan, Gui-Xian Wang, \& Jun-Min
Song (2020). Anatomical study of the left colic artery in laparoscopic-assisted colorectal surgery. Surg. Endosc., 34 (12), 53205326. DOI: 10.1007/s00464-019-07320-w

5. Yosyp Grytsenko, Anatoliy Bedeniuk, Stepan Grytsenko, Mykhailo Horman, \& Hanna Boiko (2017). The evaluation of risk factors of anastomotic leakage in patients with colorectal cancer complicated by ileus. International Journal of Surgery and Medicine, 3 (4), 205-210. DOI: 10.5455/ijsm.risk-factors-anastomoticleakage-colorectal-cancer-ileus

6. Yu-Chen Fana, Fei-Long Ninga, Chun-Dong Zhanga, \& Dong-Qiu Daia (2018). Preservation versus non-preservation of left colic artery in sigmoid and rectal cancer surgery: A meta-analysis. International Journal of Surgery, 52, 269-277. DOI: $10.1016 /$ j.ijsu.2018.02.054

7. Zebrowski, W., Augustyniak, E., \& Zajac, S. (1970). Variations of origin and branching of the interior mesenteric artery and its anastomoses. Folia Morphol. (Warsz), 30, 510-517. PMID: 5316536.

Отримано 12.03.2021

Електронна адреса для листування: stepan_grytsenko@ukr.net

I. YA. DZIUBANOVSKYI ${ }^{1}$, S. Y. GRYTSENKO${ }^{1}$, I. Y. HRYTSENKO ${ }^{2}$, A. D. BEDENIUK ${ }^{1}$,

I. Horbachevsky National Medical University ${ }^{1}$

Medical center "Omega", Kyiv

\title{
RARE ANATOMICAL VARIANTS OF THE INFERIOR MESENTERIC ARTERY BASIN AT THE PREOPERATIVE AND INTRAOPERATIVE STAGES IN PATIENTS UNDERGOING D3 LYMPH DISSECTION WITH PRESERVATION OF THE LEFT COLIC ARTERY
}

\begin{abstract}
The aim of the work: to analyze rare variants of IMA basin anatomy and study the nuances that may complicate and increase the time of D3 lymph node dissection with preservation of LCA.

Materials and Methods. The study included 103 patients (56 men and 47 women; mean age (64.2 \pm 11.6$)$ ) with cancer of the left half of the colon and rectum who underwent preoperative 3D-CT angiography in Ternopil University Hospital between 2016 and 2021 years. In this study, we set the following objectives: to determine the type of IMA, the distance from the root of the IMA to the aortic bifurcation, the distance from the IMA to the LCA, the distance from the LCA to the junction with the IMV.

Results and Discussion. All our patients underwent D3 lymph node dissection with LCA preservation. Anastomotic leakage did not occur in any patient. The average number of removed lymph nodes was (21.4 \pm 7.1$)(12-45)$. The frequency of metastatic lesions of the apical group of lymph nodes was $7.5 \%$. One of the rarest variants of Zebrowski IMA branching is types C, D and G. In our study, we found that the distance of LCA from the IMA was $(35.29 \pm 10.18) \mathrm{mm}(11-66 \mathrm{~mm})$. Particular attention should be paid to clinical cases with a distance of LCA from the IMA more than $5 \mathrm{~cm}$, which also contributes to the increased operation time required for skeletonization of the above vessels and compliance with all oncological canons of D3 lymph node dissection. We found rare cases of high IMA discharge at the level of the renal arteries. Another reference point to pay attention to is the intersection of LCA with IMV, which according to our analysis is (20.97 \pm 13.59$) \mathrm{mm}$ (range 2-65).
\end{abstract}

Key words: 3D-CT angiography; colorectal cancer; D3 lymph dissection; left colic artery. 


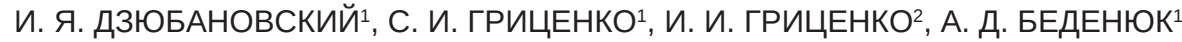

Тернопольский национальный медицинский университет имени И. Я. Горбачевского МОз Украины ${ }^{1}$ Медицинский центр “Омега" , Киев

\title{
РЕДКИЕ АНАТОМИЧЕСКИЕ ВАРИАНТЫ БАССЕЙНА НИЖНЕЙ БРЫЖЕЕЧНОЙ АРТЕРИИ НА ПРЕДОПЕРАЦИОННОМ И ИНТРАОПЕРАЦИОННОМ ЭТАПАХ У ПАЦИЕНТОВ, КОТОРЫМ ВЫПОЛНЯЕТСЯ ДЗ ЛИМФОДИССЕКЦИЯ С СОХРАНЕНИЕМ ЛЕВОЙ ОБОДОЧНОЙ АРТЕРИИ
}

\begin{abstract}
Цель работы: провести анализ редких вариантов анатомии бассейна нижней брыжеечной артерии и изучить трудности, которые могут затруднять и увеличивать время проведения ДЗ лимфодиссекции с сохранением левой ободочной артерии. Материалы и методы. В исследование включили 103 пациента (56 мужчин и 47 женщин, средний возраст (64,2 土 11,6) года), больных раком левой половины ободочной и прямой кишок, которым была проведена предоперационная ЗД-КТ ангиография в Тернопольской университетской больнице в период 2016-2021 гг. В данном исследовании мы ставили следующие задачи: определить тип нижней брыжеечной артерии, расстояние от устья нижней брыжеечной артерии к бифуркации аорты, расстояние от нижней брыжеечной артерии к левой ободочной артерии, расстояние от левой ободочной артерии к месту перекреста с нижней брыжеечной веной.

Результаты исследований и их обсуждение. Всем пациентам была выполнена ДЗ лимфодиссекция с сохранением левой ободочной артерии. Ни в одного пациента не возникла несостоятельность швов анастомоза. Среднее количество удаленных лимфатических узлов составила 21,4 \pm 7,1 (12-45). Частота метастатического поражения апикальной группы лимфатических узлов составила 7,5 \%. Одними из самых редких вариантов ветвления нижней брыжеечной артерии по Зебровскому являются типы C, D и G. B нашем исследовании мы обнаружили, что расстояние отхождения левой ободочной артерии от нижней брыжеечной артерии составляет $(35,29 \pm 10,18)$ мм $(11-66$ мм). Особо следует обратить внимание на клинические случаи с расстояния отхождения левой ободочной артерии от нижней брыжеечной артерии больше 5 см, что также вносит свои трудности в увеличении времени операции, необходимой для скелетизации вышеупомянутых сосудов и соблюдения всех онкологических канонов ДЗ лимфодиссекции. Мы обнаружили редкие случаи высокого отхождения нижней брыжеечной артерии на уровне почечных артерий. Еще одним ориентиром, на который следует обращать внимание, это перекрест левой ободочной артерии с нижней брыжеечной веной, который согласно нашему анализу составляет $(20,97 \pm 13,59)$ мм (диапазон 2-65).
\end{abstract}

Ключевые слова: ЗД-КТ ангиография; колоректальный рак; ДЗ лимфодиссекция; левая ободочная артерия. 